Svitlana KHALATUR

Dnipro State Agrarian and Economic University, Ukraine

DOI : $10.14746 /$ ps.2020.1.28

https://orcid.org/0000-0001-8331-3341

\title{
Kateryna ZHYLENKO
}

Oles Honchar Dnipro National University, Ukraine

https://orcid.org/0000-0002-3942-9467

\section{Ihor VINICHENKO}

Dnipro State Agrarian and Economic University, Ukraine https://orcid.org/0000-0002-9527-1625

\section{Olena TROKHYMETS}

Classic Private University, Ukraine

ORCID: https://orcid.org/0000-0001-7587-7948

\section{Lesia KRIUCHKO}

Dnipro State Agrarian and Economic University, Ukraine https://orcid.org/0000-0002-7490-3523

\section{THE FORMATION OF THE INTERNATIONAL IMPERATIVES OF THE NATIONAL (FOOD) SECURITY COEFFICIENT IN UKRAINE UNDER GLOBALIZATION}

Methods. In the course of the research, general scientific methods of cognition and evaluation of the objective nature of the transformation of economic phenomena and processes, fundamental provisions of the food security theory, instrumental and methodical apparatus of economic research in macroeconomics were applied.

Novelty of the research. The authors found that it is efficient to construct a regression model to analyze the food production index, because it not only allows to estimate the degree of influence of factor traits on the result, but also to most effectively predict the size of the food production index for the future, using statistically available criteria.

Practical significance. Studying of the food security indicators of the EU and Ukraine ranks create the opportunity to most effectively predict the size of the Food production index for the future.

The aim of the study is to study the imperatives of the national (food) security coefficient formation in Ukraine, based on the analysis of the existing system of indicators used to assess the state of the food security system in the country.

To achieve this goal the following tasks are set and solved:

- to investigate and substantiate the imperatives of Ukraine's national (food) security coefficient formation in the context of globalization; 
- to analyze the Global Food Security Index Ranks of Europe and Ukraine; consumer expenditures spent on food that were consumed at home in Ukraine;

- to determine the current state of food security indicators in the EU and Ukraine.

\section{INTRODUCTION}

The level of food security is an important element in public policy in today's context. In general, food security is measured by the quantity and quality of food sufficient for the normal physical and intellectual development of a person. In addition, each country has its own peculiarities and traits, which are caused by centuries-old formation in the process of changing generations, differences in the physiology of the organism, the territorial location of the state. As for Ukraine, the problem of achieving food security is of particular importance. At the present time there is a rather low standard of living and social protection of large sections of the population, a decline in the level of the nation health and crisis demographic processes. These are factors that determine the need to take measures to ensure food security of Ukraine, improve the directions of state policy and national security of the state.

Problems are formed on the basis of food safety, quality and energy value to ensure a healthy and active lifestyle. It is on the basis of a database of questions in many countries, as well as in Ukraine, that a system of indicators and coefficients has been developed to study the state and level of food security. The urgency of assessing the formation of food security in the globalization changes and trends is connected with the need to increase the competitiveness of Ukrainian agricultural products on the world market.

\section{LITERATURE REVIEW}

Yosef Alamri, Abdulaziz Al-Duwais (2019) write that the importance of agriculture sector came from solving many of the financial problems developing countries are facing, such as low-income rate, high unemployment rate, the deficit in the balance of payments, and lower the central banks of foreign currency reserves. Finally, production, imports, and consumption are the most critical factors that affect food security coefficient for wheat, barley, and poultry in Saudi Arabia. The purpose of the study of Giscard Assoumou-Ella (2019) was to analyze the effect of external trade on food security of the CEMAC countries. Indeed, like other developing countries, they have adopted a development model based on commodity production for export to industrialized economies.

Olarinre Abiola Adebunmi, Oladeebo Job Olatunji, Olarinde Luke O. (2019) studied Effects of Land Management Practices on Food Security of Farming Households in Osun State. Social and economic characteristics had significant effect on the choice of land management practices in the study area.

Tarek Ben Hassen, Hamid El Bilali (2019) define that the great challenge for the coming decades will be the task of increasing food production to ensure food security 
for a world population of 7.6 billion people, and expected to be 9 million by 2050 . Food security is a holistic concept that involves economic, social, cultural, environmental and political aspects. However, food security is still a misunderstood operational concept in the public policy in the GCC. Onyango George Nyakoyo, Abuya Isaac Odhiambo (2020) note that food insecurity is one of the most challenging development problem in Kenya. It is recommended that stakeholder involvement should be enhanced in sustainable community food security projects to promote timely implementation and completion of sustainable community food security projects, reduce the cost of implementation, ensure sustainable farming practices. It is also recommended that stakeholder involvement should be integrated in sustainable community food security policies and projects.

Charles L. Tumuhe, Jackson Kusiima, William Sekamate, Matia Mulumba (2020) argue that like many other businesses, the food sector is not spared from challenges both structural and logistical. To most of these challenges, a solution has been suggested and these can be tested out over time through a multi-sectoral engagement.

Natalia Vasylieva (2019) writes that an important challenge facing international agriculture is the acute problem of covering food shortages in all countries. Irina Petrova and Mohamed Albdrane (2019) study theoretical and practical means of recruiting the staff motivation at small food industry enterprises in their research, because constant and rapid changes in the internal and external environment of enterprises, as well as in the style of human behavior, require completely new approaches to decision making in the field of motivation. Alina Bukhtiarova, Arsen Hayriyan, Victor Chentsov and Sergii Sokol (2019) argue that the agricultural sector is a strategically important component of the national economy as it forms a significant part of the country's gross product, provides a significant portion of export earnings and provides jobs to millions of people.

Olga Vyshnevska, Olena Kaliuzhna, Inna Irtyshcheva (2019) determine that globalization processes have stimulated the formation of a global market, which has significantly increased the need to strengthen the competitive position of commodity producers. Competitive positions of producers of goods, especially agricultural products, depend on the formation of the process of food security of individual countries and regions of the world. Anton Stolitnii, Vitalii Makhinchuk (2019) argue that global and, in particular, European tendencies to transform the social and economic development of countries on the basis of new, more effective growth vectors are accompanied by profound changes in national systems of public economic development management. Maksym Odnorog, Nataliia Kraus, Liudmyla Savchuk (2019) study the genesis of a new institutional theory in order to understand the role of the institutional environment in shaping and improving food security in the country.

Svitlana Rogach, Larysa Vdovenko, Oleh Polishchuk (2019) write that the current system of financial support for agriculture in Ukraine is on the vector of formation and adaptation in accordance with the conditions of the European Union, substantiation of theoretical and methodological principles and development of practical recommendations for the improvement of existing international levers and regulatory mechanisms. Igor Guzhva, Petro Nebotov, Yevhen Ivanov (2019) argue that diversification of production processes across regions and countries contributes to reducing trade costs 
through the development of information and communication technologies. This factor has a huge impact on the acceleration of globalization, since it leads to the inclusion of new markets and the country's goals in the processes of reproduction in the world, stimulates the spread of innovation, scientific and technological progress, and the creation of new jobs.

Hanna Fedosieieva (2019) notes that concerning agriculture, national goals for sustainable development of Ukraine in this direction are determined by: doubling the productivity of agriculture, ensuring the creation of sustainable food production systems that contribute to the conservation of ecosystems.

So the analysis of literature sources has shown that the imperatives of food security in the context of globalization are insufficiently studied.

Setting objectives. The purpose of the article is to study the imperatives of the national (food) security coefficient formation in Ukraine, based on the analysis of the existing system of indicators used to assess the state of the food security system in the country.

\section{RESEARCH METHODS}

In the course of the research, general scientific methods of cognition and evaluation of the objective nature of the transformation of economic phenomena and processes, fundamental provisions of the food security theory, instrumental and methodical apparatus of economic research in macroeconomics were applied.

The following methods of economic research have been used to substantiate scientific provisions, conclusions, and proposals: functional and structural analysis (to form the purpose of the study, identify cause and effect relationships between results and factors); systematic analysis (to structure conditions and key factors, select methods and tools to influence global food security processes); statistical (for the systematization, processing and quantitative analysis of food safety information); graphical and tabular (to illustrate patterns and trends in macroeconomic activity); economic and mathematical analysis (to identify trends in food security indicators and mathematically interpret their trend); pair and multifactorial relationships between factors and results) empirical method and qualitative analysis (for studying and evaluating the practical aspects of food security management, as well as developing mechanisms for putting scientific provisions and models into practice).

\section{RESULTS}

Thus, in order to study the imperatives of forming the national (food) security coefficient in Ukraine, we will analyze the existing system of indicators that assess the state of the food security system in the country.

According to the Law of Ukraine "On National Security of Ukraine" of June 21, 2018 No. 2469-VIII, threats to the national security of Ukraine are phenomena, tendencies and factors that make it impossible or complicate the realization of national 
interests and the preservation of national values of Ukraine. According to the same law, Ukraine's national security is defined as the protection of state sovereignty, territorial integrity, democratic constitutional order and other national interests of Ukraine against real and potential threats.

Therefore, national food security in the broad sense should be considered as the state of the economy, and more narrowly - as a guaranteed ability of the state to meet the needs of the population for each citizen of food in the required volume, range and quality at a level that provides health and intellectual personal development, on the principles of self-sufficiency of basic products and their economic and physical accessibility, regardless of the influence of external and internal factors. Based on the analysis, we consider it expedient to approve food security imperatives, where it is necessary to point out the prospects for the development of the agricultural sector of its individual branches, to determine the totality of state measures that are necessary to ensure the optimal level of food security in the context of globalization.

According to the CIS Food Security Improvement Concept, approved by the CIS Council of Ministers Decision of 19 November 2010, the main objective of the social and economic development of the CIS member states (including Ukraine) and food security is to improve the quality of life of the CIS population. Food security is an integral part of the economic security of the CIS member states, a key factor in preserving their statehood and sovereignty, an essential component of the life support system and demographic policies.

According to this concept, the state food security is the state of the economy of the state, in which, due to its own production, the food independence of the country is ensured and the physical and economic accessibility of the basic types of food and clean drinking water is guaranteed for the whole population in the quantity and quality necessary for an active and healthy life, implementing demographic policies. And food independence is defined as the state of the economy, in which the actual production of vital foodstuffs per year is at least $80 \%$ of the annual population's demand for these foods in accordance with physiological standards of nutrition. Indicators are used to assess the level of food independence of CIS countries, including:

- the daily nutritional and energy value of the human diet;

- the level of consumption sufficiency of each individual food;

- the level of adequacy of grain reserves in state resources;

- economic availability of food;

- capacity of the internal market of individual products;

- the degree of food independence for individual products;

- the level of sufficient supply of clean drinking water.

FAO defines food security as the situation where all people have, at all times, physical, social and economic access to adequate, safe and nutritious food that meets their dietary needs and nutritional preferences for an active and healthy life.

The Decree of the Cabinet of Ministers of Ukraine on December 5, 2007 N 1379 approved the Methodology for determining the main food security indicators, with the aim of determining the main food security indicators. Indicators characterizing the state of food security of the state (region) are calculated according to the following main food groups: bread and bread products; potato; vegetables, melons; fruits, berries 
and grapes; sugar; oil; meat and meat products; milk and milk products; fish and fish products; eggs.

Food security indicators are:

1) the daily energy value of the human diet, which is defined as the sum of the product per unit mass of certain types of products consumed by the person during the day, and their energy value;

2) providing the human diet with basic types of products, which is defined as the ratio between the actual consumption of an individual product and its rational norm;

3 ) the adequacy of grain reserves in state resources, which is defined as the ratio between the volume of food grain in the state food reserve and the volume of domestic consumption of bread and bread products in terms of grain;

4) economic affordability of products, which is defined as the proportion of total food expenditure in the aggregate total household expenditure;

5) differentiation of the cost of food by social groups, which is monitored in dynamics and is calculated as the ratio between the cost of nutrition of 20 percent of the highest income households and the cost of nutrition of 20 percent of the lowest income households;

6) the capacity of the domestic market of individual products, which is monitored in dynamics and is defined in natural terms as the product of consumption of a certain product and the average annual population;

7) food independence for an individual product, defined as the ratio between the import values of an individual product in kind and the capacity of its internal market.

According to the Global Food Security Index, food security is defined as a condition in which people at all times have the physical, social and economic access to adequate and nutritious food that meets their nutritional needs for a healthy and active life. Using this definition, the Global Food Security Index addresses major accessibility and quality issues in a number of 113 countries. The Global Food Security Index is a dynamic quantitative and qualitative assessment model built on 34 unique indicators that measures these drivers of food security in both developing and developed countries. In Table 1 the Global Food Security Index Ranks of European countries are analyzed.

Global Food Security Index. Ranks are based on countries' 2019, natural resources $\&$ resilience performance*

\begin{tabular}{|r|l|c|c|l|c|}
\hline $\begin{array}{c}\text { Global } \\
\text { ranking }\end{array}$ & Country & $\begin{array}{c}\text { Food Security } \\
\text { Index }\end{array}$ & $\begin{array}{c}\text { Regional ranking, } \\
\text { Europe }\end{array}$ & Country & $\begin{array}{c}\text { Food Security } \\
\text { Index }\end{array}$ \\
\hline 1 & \multicolumn{1}{|c|}{2} & 3 & 4 & \multicolumn{1}{c|}{5} & 6 \\
\hline 1st & Czech Republic & 75.5 & 1st & Czech Republic & 75.5 \\
\hline 2nd & Finland & 74.0 & 2nd & Finland & 74.0 \\
\hline =3rd & Denmark & 73.9 & 3rd & Denmark & 73.9 \\
\hline 5th & Slovakia & 73.1 & 4th & Slovakia & 73.1 \\
\hline =6th & Sweden & 72.1 & $=5$ th & Sweden & 72.1 \\
\hline$=6$ th & Switzerland & 72.1 & $=5$ th & Switzerland & 72.1 \\
\hline 9th & Ireland & 71.0 & 7th & Ireland & 71.0 \\
\hline$=10$ th & Austria & 69.6 & $=8$ th & Austria & 69.6 \\
\hline$=10$ th & Poland & 69.6 & $=8$ th & Poland & 69.6 \\
\hline
\end{tabular}




\begin{tabular}{|c|l|c|c|l|c||}
\hline 1 & \multicolumn{1}{|c|}{2} & 3 & 4 & \multicolumn{1}{|c||}{5} & 6 \\
\hline 12 th & Hungary & 69.5 & 10 th & Hungary & 69.5 \\
\hline 13 th & Norway & 69.0 & 11 th & Norway & 69.0 \\
\hline 18 th & Germany & 68.4 & 12 th & Germany & 68.4 \\
\hline 19 th & France & 68.3 & 13 th & France & 68.3 \\
\hline 20th & Netherlands & 67.4 & 14 th & Netherlands & 67.4 \\
\hline 22nd & Spain & 66.3 & 15 th & Spain & 66.3 \\
\hline 23rd & Romania & 66.2 & 16 th & Romania & 66.2 \\
\hline$=24$ th & Bulgaria & 65.3 & 17 th & Bulgaria & 65.3 \\
\hline$=28$ th & Greece & 64.8 & $=19$ th & Greece & 64.8 \\
\hline$=28$ th & Portugal & 64.8 & $=19$ th & Portugal & 64.8 \\
\hline 30th & Italy & 64.5 & $21 \mathrm{st}$ & Italy & 64.5 \\
\hline$=33 \mathrm{rd}$ & Belgium & 62.9 & $23 \mathrm{rd}$ & Belgium & 62.9 \\
\hline 40th & United States & 61.4 & 24 th & Serbia & 62.2 \\
\hline$=53 \mathrm{rd}$ & Ukraine & 57.0 & 25 th & Ukraine & 57.0 \\
\hline$=59$ th & Belarus & 56.0 & 26 th & Belarus & 56.0 \\
\hline
\end{tabular}

* Compiled by the authors.

Czech Republic ranks first in both the World and Regional Food Security Index of Europe. A total of 113 countries were analyzed, Bahrain is the last in the global ranking. Singapore is on the 109 place. Ukraine is ranked 53rd in the Global Food Security Index and 25th in the European Regional Rating. Table 2 analyzes the concentration of consumer expenditures spent on food that were consumed at home in Ukraine.

Table 2

Consumer expenditures spent on food that were consumed at home

\begin{tabular}{|l|r|r|r|r|r|r|c||}
\hline \multicolumn{1}{|c|}{ Ukraine } & $\mathbf{2 0 1 3}$ & $\mathbf{2 0 1 4}$ & $\mathbf{2 0 1 5}$ & $\mathbf{2 0 1 6}$ & $\mathbf{2 0 1 7}$ & $\mathbf{2 0 1 8}$ & $\begin{array}{c}\text { Change, } \\
\text { \% }\end{array}$ \\
\hline $\begin{array}{l}\text { Share of consumer expenditures spent on food } \\
\text { that were consumed at home, percent }\end{array}$ & 38.1 & 38.4 & 39.4 & 40.3 & 42.1 & 42.2 & 110.76 \\
\hline $\begin{array}{l}\text { Consumer expenditures, U.S. dollars per person } \\
\text { Expenditure on food, U.S. dollars per person }\end{array}$ & 1100 & 818 & 535 & 563 & 716 & 858 & 77.94 \\
\hline
\end{tabular}

Source: USDA.

After analyzing Table 2, we can see an increase of Share of consumer spending on food that was consumed at home by almost $11 \%$ in 2018 compared to 2013 . U.S. consumer expenditures and expenditure on food metrics dollars per person decreased for the analyzed period by $29.63 \%$ and $22.06 \%$ respectively. Table 3 analyzes the food security indicators of the EU and Ukraine over the 2001-2018 average. In particular, the following indicators: food exports ( $\%$ of merchandise exports); food imports ( $\%$ of merchandise imports); food production index $(2004-2006=100)$; food, beverages and tobacco ( $\%$ of value added in manufacturing).

Food exports as a \% of commodity exports include food and live animals, beverages and tobacco, animal and vegetable oils, oil seeds, oil nuts and kernels. Food imports in \% of commodity imports include the same goods. The Food production Index covers crops that are considered edible and contain nutrients. Coffee and tea are excluded because they have no nutritional value. 
Food security indicators of the EU and Ukraine, on average, 2001-2018

\begin{tabular}{|c|c|c|c|c|c|c|}
\hline $\begin{array}{l}\text { Country } \\
\text { Name }\end{array}$ & $\begin{array}{c}\text { Food } \\
\text { exports }(\% \\
\text { of } \\
\text { merchandi- } \\
\text { se exports) }\end{array}$ & $\begin{array}{l}\text { Food im- } \\
\text { ports (\% } \\
\text { of mer- } \\
\text { chandise } \\
\text { imports) }\end{array}$ & $\begin{array}{c}\text { Food } \\
\text { produc- } \\
\text { tion index } \\
(2004-2006 \\
=100)\end{array}$ & \begin{tabular}{|c|} 
Food, beve- \\
rages and \\
tobacco \\
(\% of value \\
added in ma- \\
nufacturing)
\end{tabular} & $\begin{array}{l}\text { Agricultural } \\
\text { land }(\% \text { of } \\
\text { land area) }\end{array}$ & $\begin{array}{l}\text { Agricultural } \\
\text { land (sq. km) }\end{array}$ \\
\hline Austria & 6.71 & 6.98 & 101.62 & 9.93 & 33.91 & $27,997.78$ \\
\hline Belgium & 8.99 & 8.60 & 97.43 & 14.05 & 44.97 & $13,617.63$ \\
\hline Bulgaria & 13.40 & 7.75 & 108.43 & 18.61 & 47.38 & $51,530.56$ \\
\hline Croatia & 11.77 & 10.40 & 108.19 & 25.03 & 23.58 & $13,194.56$ \\
\hline Cyprus & 36.39 & 14.62 & 91.01 & 37.75 & 14.27 & $1,318.59$ \\
\hline Czech Republic & 4.16 & 5.46 & 98.77 & 9.33 & 52.62 & $40,648.75$ \\
\hline Denmark & 18.62 & 12.79 & 102.36 & 16.66 & 62.69 & $26,512.50$ \\
\hline Estonia & 9.68 & 10.22 & 115.67 & 13.82 & 21.24 & $9,066.63$ \\
\hline Finland & 2.31 & 6.68 & 98.58 & 8.36 & 7.47 & $22,723.13$ \\
\hline France & 11.85 & 8.66 & 100.34 & 15.98 & 53.19 & $291,244.39$ \\
\hline Germany & 5.14 & 7.64 & 103.75 & 7.88 & 48.32 & $168,526.25$ \\
\hline Greece & 20.35 & 12.30 & 96.77 & 26.33 & 58.09 & $74,880.00$ \\
\hline Hungary & 7.53 & 4.56 & 92.11 & 11.75 & 62.17 & $55,988.13$ \\
\hline Ireland & 9.36 & 9.92 & 101.17 & 17.53 & 63.65 & $43,850.06$ \\
\hline Italy & 7.56 & 9.60 & 95.81 & 10.29 & 48.12 & $141,543.13$ \\
\hline Latvia & 15.00 & 13.33 & 118.18 & 21.34 & 28.65 & $17,820.31$ \\
\hline Lithuania & 15.55 & 10.92 & 111.02 & 22.85 & 44.71 & $28,021.87$ \\
\hline Luxembourg & 8.10 & 10.84 & 98.76 & 9.98 & 53.50 & $1,300.06$ \\
\hline Malta & 6.00 & 11.40 & 98.21 & 15.71 & 31.02 & 99.27 \\
\hline Norway & 7.23 & 8.17 & 101.01 & 17.69 & 2.78 & $10,160.24$ \\
\hline Poland & 10.61 & 7.30 & 104.21 & 19.12 & 50.42 & $154,419.38$ \\
\hline Romania & 6.79 & 7.60 & 97.69 & 16.72 & 61.05 & $140,396.88$ \\
\hline Slovak Republic & 4.09 & 5.79 & 93.01 & 7.82 & 41.19 & $19,811.37$ \\
\hline Slovenia & 3.80 & 7.39 & 95.05 & 7.70 & 28.16 & $5,671.22$ \\
\hline Spain & 15.14 & 10.34 & 102.77 & 17.54 & 55.91 & $279,194.00$ \\
\hline Sweden & 4.68 & 8.93 & 98.68 & 7.62 & 7.59 & $31,069.06$ \\
\hline Ukraine & 22.42 & 8.29 & 118.21 & 29.38 & 71.40 & $413,635.63$ \\
\hline Portugal & 10.21 & 13.44 & 101.98 & 15.85 & 40.79 & $37,342.34$ \\
\hline
\end{tabular}

Source: Compiled by authors according to the World Bank data.

According to Table 3 food exports among the analyzed countries is the largest in Cyprus (36.39\%); in Ukraine (22.42\%); and in Greece (20.35\%). Food imports is the highest in Cyprus (14.62\%); Portugal (13.44\%); Denmark (12.79\%) and the smallest in the Czech Republic (5.46\%); Hungary (4.56\%); Slovak Republic (5.79\%). The food production index is shown in detail in Figure 1.

According to Figure 1 food production index is the largest in Ukraine (118.21\%); Latvia (118.18\%); Estonia (115.67\%); and the smallest in such countries as Cyprus (91.01\%); Hungary (92.11\%); Slovak Republic (93.01\%). Ukraine is the largest producer and exporter of cereals among European countries. Table 4 compares the dynamics and forecast of harvest and crop production Wheat in Ukraine and the EU. 
Figure 1. Food production index $(2004-2006=100)$, in average 2001-2018

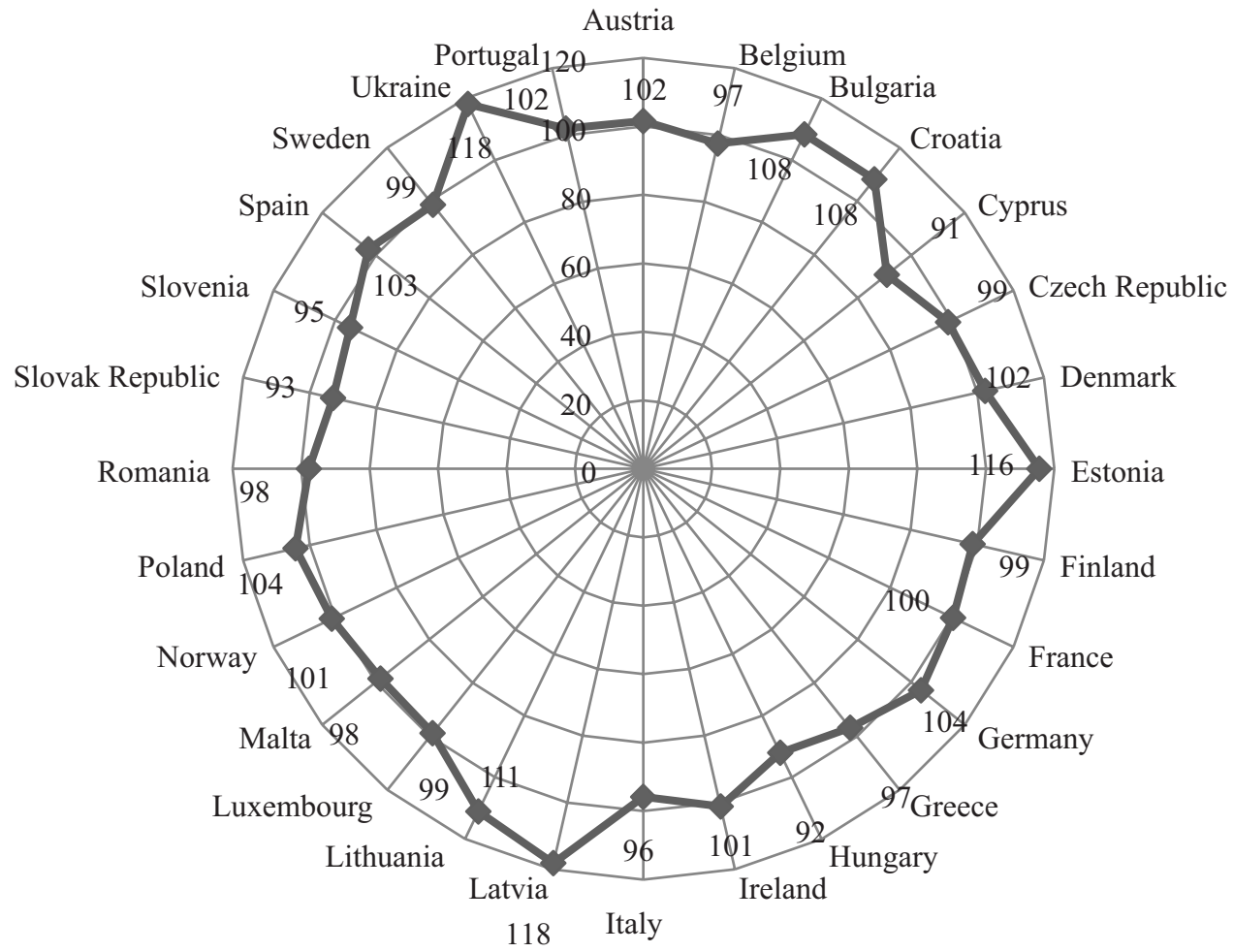

Source: World Bank data, World Development Indicators (2019), http://databank.worldbank.org.

Table 4

Dynamics and forecast of harvest and crop production wheat in Ukraine and EU

\begin{tabular}{|c|c|c|c|c|c|c|}
\hline \multirow[b]{2}{*}{ Year } & \multicolumn{3}{|c|}{ Ukraine } & \multicolumn{3}{|c|}{$\overline{\mathbf{E U}}$} \\
\hline & $\begin{array}{c}\text { Harvest } 1,000 \\
\text { hectares for } \\
\text { area }\end{array}$ & $\begin{array}{c}\text { Yield metric } \\
\text { tons per hectare } \\
\text { for yield }\end{array}$ & $\begin{array}{c}\text { Production } \\
1,000 \text { metric } \\
\text { tons }\end{array}$ & $\begin{array}{c}\text { Ha- } \\
\text { rvest }\end{array}$ & Yield & Production \\
\hline $2016 / 17$ & 6,462 & 4.15 & 26,791 & 27,232 & 5.34 & 145,369 \\
\hline $2017 / 18$ & 6,642 & 4.06 & 26,981 & 26,321 & 5.76 & 151,681 \\
\hline $2018 / 19$ & 6,900 & 3.70 & 25,500 & 25,630 & 5.36 & 137,500 \\
\hline $2019 / 20$ & 6,918 & 4.04 & 27,937 & 26,373 & 5.75 & 151,595 \\
\hline $2020 / 21$ & 6,938 & 4.07 & 28,262 & 26,483 & 5.78 & 153,142 \\
\hline $2021 / 22$ & 6,993 & 4.11 & 28,774 & 26,546 & 5.82 & 154,380 \\
\hline $2022 / 23$ & 7,040 & 4.16 & 29,262 & 26,613 & 5.85 & 155,636 \\
\hline $2023 / 24$ & 7,114 & 4.19 & 29,825 & 26,697 & 5.88 & 157,017 \\
\hline $2024 / 25$ & 7,220 & 4.21 & 30,431 & 26,773 & 5.91 & 158,332 \\
\hline $2025 / 26$ & 7,265 & 4.24 & 30,817 & 26,858 & 5.95 & 159,682 \\
\hline $2026 / 27$ & 7,369 & 4.27 & 31,452 & 26,933 & 5.98 & 160,985 \\
\hline $2027 / 28$ & 7,410 & 4.31 & 31,939 & 27,024 & 6.01 & 162,405 \\
\hline $2028 / 29$ & 7,468 & 4.35 & 32,497 & 27,089 & 6.04 & 163,692 \\
\hline
\end{tabular}

Source: USDA. 
According to the table 4 Harvest per 1,000 hectares for area in Ukraine is projected at 7,468 in 2028/29. While in the EU the same figure is planned at 27,089, which is only three times higher than in Ukraine. Wheat Yield in Ukraine is forecast at 4.35 metric tons per hectare for yield in 2028/29. EU Wheat Yield is estimated at 6.04 metric tons per hectare for yield.

Table 5

Imports, Exports and Total consumption of Wheat, dynamics and forecast in Ukraine and $\mathrm{EU}, \mathbf{1 , 0 0 0}$ metric tons

\begin{tabular}{||c|c|c|c|c|c|c||}
\hline \multirow{2}{*}{ Year } & \multicolumn{3}{|c|}{ Ukraine } & \multicolumn{2}{c|}{ EU } & $\begin{array}{c}\text { Total } \\
\text { Consumption }\end{array}$ \\
\cline { 2 - 7 } & Imports & Exports & $\begin{array}{c}\text { Total } \\
\text { consumption }\end{array}$ & Imports & Exports & 128,000 \\
\hline $2016 / 17$ & 41 & 18,107 & 10,300 & 5,299 & 27,426 & 130,400 \\
\hline $2017 / 18$ & 58 & 17,775 & 9,800 & 5,824 & 23,290 & 125,000 \\
\hline $2018 / 19$ & 25 & 16,500 & 9,200 & 6,000 & 23,000 & 128,697 \\
\hline $2019 / 20$ & 56 & 18,442 & 9,199 & 6,144 & 29,083 & 129,080 \\
\hline $2020 / 21$ & 59 & 19,163 & 9,155 & 6,169 & 30,231 & 129,431 \\
\hline $2021 / 22$ & 62 & 19,737 & 9,097 & 6,166 & 31,115 & 129,763 \\
\hline $2022 / 23$ & 62 & 20,286 & 9,038 & 6,154 & 32,026 & 130,102 \\
\hline $2023 / 24$ & 62 & 20,909 & 8,977 & 6,111 & 33,027 & 130,437 \\
\hline $2024 / 25$ & 60 & 21,568 & 8,919 & 6,110 & 34,005 & 130,767 \\
\hline $2025 / 26$ & 58 & 22,018 & 8,854 & 6,118 & 35,033 & 131,089 \\
\hline $2026 / 27$ & 56 & 22,714 & 8,792 & 6,112 & 36,008 & 131,414 \\
\hline $2027 / 28$ & 54 & 23,262 & 8,730 & 6,094 & 37,085 & 131,726 \\
\hline $2028 / 29$ & 52 & 23,877 & 8,671 & 6,082 & 38,047 & \\
\hline
\end{tabular}

Source: USDA.

According to the table 5, forecasts of Wheat Imports and Exports in Ukraine and the EU are for 2028/29 years 52,000 metric tons, 23,877,000 metric tons, 6,082,000 metric tons, 38,047,000 metric tons respectively. Thus, Ukraine imports small quantities of wheat.

Table 6

Dynamics and forecast of harvest and production of Corn in Ukraine and EU

\begin{tabular}{|c|c|c|c|c|c|c|}
\hline \multirow[b]{2}{*}{ Year } & \multicolumn{3}{|c|}{$\overline{\mathbf{E U}}$} & \multicolumn{3}{|c|}{$\overline{\text { UKRAINE }}$} \\
\hline & $\begin{array}{c}\text { Harvest 1,000 } \\
\text { hectares for } \\
\text { area }\end{array}$ & $\begin{array}{l}\text { Yield metric } \\
\text { tons per hecta- } \\
\text { re for yield }\end{array}$ & $\begin{array}{c}\text { Production } \\
1,000 \text { metric } \\
\text { tons }\end{array}$ & Harvest & Yield & $\begin{array}{l}\text { Produc- } \\
\text { tion }\end{array}$ \\
\hline $2016 / 17$ & 8,566 & 7.22 & 61,888 & 4,239 & 6.60 & 27,969 \\
\hline $2017 / 18$ & 8,372 & 7.44 & 62,277 & 4,433 & 5.44 & 24,115 \\
\hline $2018 / 19$ & 8,250 & 7.39 & 61,000 & 4,500 & 6.89 & 31,000 \\
\hline $2019 / 20$ & 8,296 & 7.47 & 61,977 & 4,453 & 6.61 & 29,419 \\
\hline $2020 / 21$ & 8,343 & 7.54 & 62,888 & 4,537 & 6.70 & 30,398 \\
\hline $2021 / 22$ & 8,390 & 7.61 & 63,810 & 4,599 & 6.79 & 31,241 \\
\hline $2022 / 23$ & 8,439 & 7.67 & 64,758 & 4,652 & 6.88 & 32,010 \\
\hline $2023 / 24$ & 8,483 & 7.74 & 65,687 & 4,718 & 6.97 & 32,877 \\
\hline $2024 / 25$ & 8,532 & 7.81 & 66,661 & 4,770 & 7.06 & 33,659 \\
\hline $2025 / 26$ & 8,579 & 7.88 & 67,631 & 4,802 & 7.14 & 34,293 \\
\hline $2026 / 27$ & 8,631 & 7.95 & 68,651 & 4,845 & 7.23 & 35,030 \\
\hline $2027 / 28$ & 8,679 & 8.03 & 69,658 & 4,897 & 7.31 & 35,813 \\
\hline $2028 / 29$ & 8,731 & 8.10 & 70,701 & 4,955 & 7.40 & 36,644 \\
\hline
\end{tabular}

Source: USDA. 
Imports, Exports and Total consumption of Corn Crop in Ukraine and EU, 1,000 metric tons

\begin{tabular}{||c|c|c|c|c|c|c||}
\hline \hline \multirow{2}{*}{ Year } & \multicolumn{3}{|c|}{ EU } & \multicolumn{3}{c||}{ UKRAINE } \\
\cline { 2 - 7 } & Imports & Exports & Total consumption & Imports & Exports & Total consumption \\
\hline $2016 / 17$ & 15,021 & 2,189 & 74,000 & 29 & 21,334 & 6,500 \\
\hline $2017 / 18$ & 18,000 & 1,700 & 76,500 & 45 & 18,500 & 5,800 \\
\hline $2018 / 19$ & 19,500 & 1,500 & 82,500 & 25 & 25,000 & 6,200 \\
\hline $2019 / 20$ & 17,861 & 1,514 & 78,215 & 53 & 23,002 & 6,470 \\
\hline $2020 / 21$ & 17,144 & 1,528 & 78,393 & 53 & 23,886 & 6,565 \\
\hline $2021 / 22$ & 16,996 & 1,542 & 79,156 & 54 & 24,608 & 6,686 \\
\hline $2022 / 23$ & 16,950 & 1,557 & 80,043 & 54 & 25,178 & 6,886 \\
\hline $2023 / 24$ & 16,980 & 1,571 & 80,980 & 55 & 25,931 & 7,001 \\
\hline $2024 / 25$ & 17,038 & 1,586 & 82,006 & 55 & 26,546 & 7,168 \\
\hline $2025 / 26$ & 17,186 & 1,600 & 83,110 & 55 & 26,960 & 7,388 \\
\hline $2026 / 27$ & 17,256 & 1,615 & 84,184 & 55 & 27,509 & 7,576 \\
\hline $2027 / 28$ & 17,336 & 1,630 & 85,253 & 55 & 28,090 & 7,777 \\
\hline $2028 / 29$ & 17,372 & 1,645 & 86,315 & 55 & 28,797 & 7,902 \\
\hline
\end{tabular}

Source: USDA.

For further analysis among the countries of the European Union, we have selected the countries in which Agricultural land (\% of land area) is the largest. These are Denmark (62.69\%; 26,512.50 sq. Km); Hungary (62.17\%; 55,988.13 sq. Km); Ireland (63.65\%; 43,850.06 sq. Km); Romania (61.05\%; 140,396.88 sq. Km). Ukraine has the largest Agricultural land, which is $71.40 \%$ of land area, $413,635.63$ sq. km.

Figure 2. Dynamics of Food imports, \% of merchandise imports

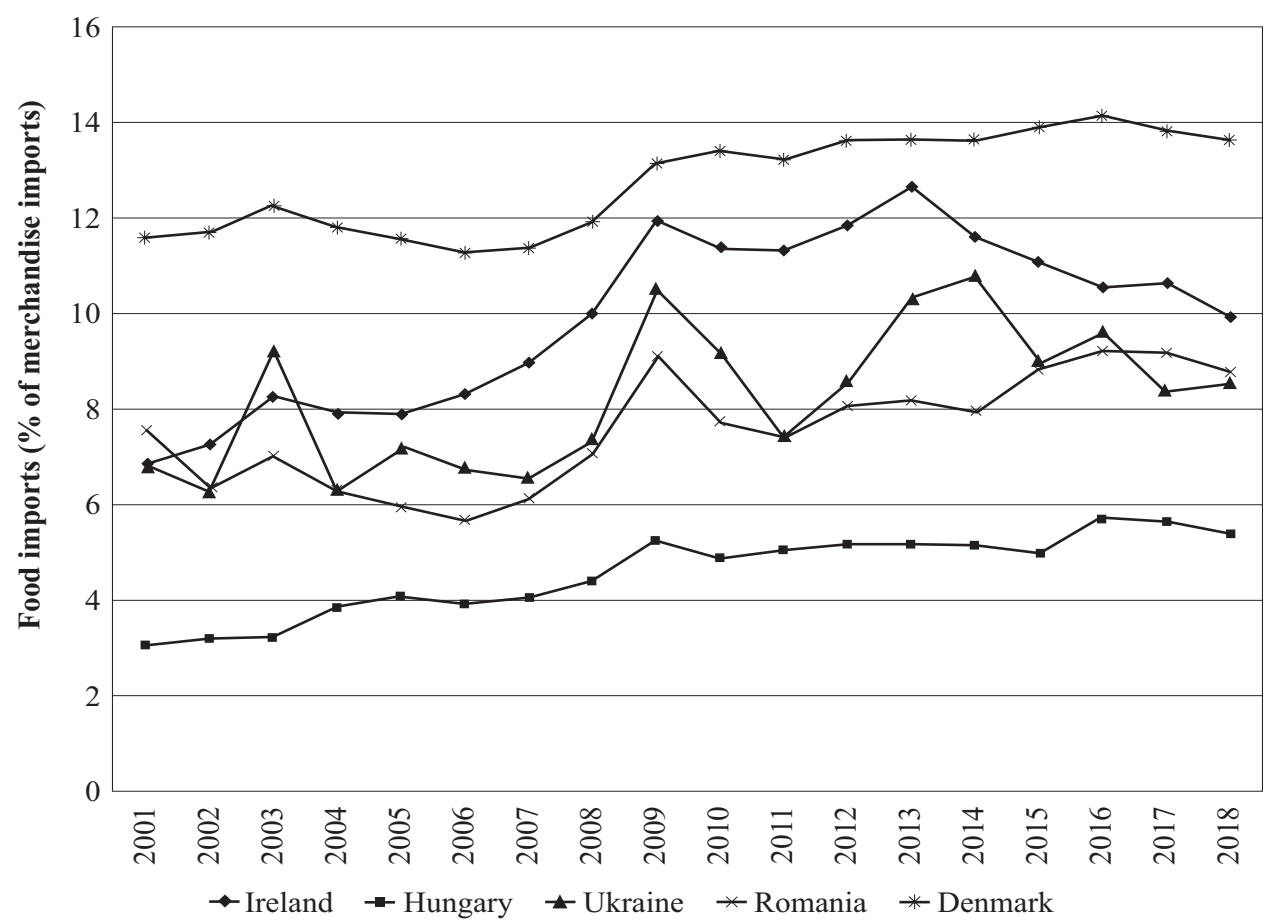

Source: World Bank data, World Development Indicators (2019): http://databank.worldbank.org. 
The Suite of Food security indicators is analyzed in Table 8.

Table 8

Food Security Indicators (3-year average), 2016-2018, \%

\begin{tabular}{||l|c|c|c|}
\hline \multicolumn{1}{|c|}{ Area } & $\begin{array}{c}\text { Prevalence of severe } \\
\text { food insecurity in } \\
\text { the total population } \\
\text { (percent) }\end{array}$ & $\begin{array}{c}\text { Prevalence of mode- } \\
\text { rate or severe food } \\
\text { insecurity in the total } \\
\text { population (percent) }\end{array}$ & $\begin{array}{c}\text { Number of severely } \\
\text { food insecure people } \\
\text { (million) }\end{array}$ \\
\hline Austria & 1.2 & 4.4 & 0.1 \\
\hline Belgium & 3.6 & 10.3 & 0.4 \\
\hline Bulgaria & 2.1 & 11.8 & 0.1 \\
\hline Croatia & 0.9 & 7.8 & $<0.1$ \\
\hline Czechia & $<0.5$ & 3.8 & $<0.1$ \\
\hline Denmark & 1.0 & 5.3 & 0.1 \\
\hline Estonia & 1.3 & 8.6 & 0.1 \\
\hline Finland & 2.0 & 8.3 & 0.5 \\
\hline France & 0.8 & 6.4 & 0.6 \\
\hline Germany & 0.7 & 3.6 & 0.3 \\
\hline Greece & 2.8 & 17.4 & 0.1 \\
\hline Hungary & 0.8 & 8.3 & 0.1 \\
\hline Ireland & 2.8 & 6.6 & 0.6 \\
\hline Italy & 1.0 & 7.1 & $<0.1$ \\
\hline Latvia & 1.2 & 10.0 & $<0.1$ \\
\hline Lithuania & $<0.5$ & 11.2 & $<0.1$ \\
\hline Luxembourg & 0.8 & 3.3 & 0.2 \\
\hline Netherlands & 1.3 & 4.3 & 0.1 \\
\hline Norway & 1.1 & 5.1 & 0.3 \\
\hline Poland & 0.7 & 5.3 & 0.3 \\
\hline Portugal & 3.2 & 11.5 & 0.8 \\
\hline Romania & 4.0 & 14.7 & 0.1 \\
\hline Slovakia & $<0.5$ & 4.7 & 0.1 \\
\hline Spain & 1.5 & 5.5 & 0.8 \\
\hline Sweden & 1.0 & - & \\
\hline Ukraine & 1.8 & & 0.7 \\
\hline
\end{tabular}

Source: Compiled by authors according to the World Bank data.

According to the Food Security Improvement Concept of the CIS Member States, the following risks and threats to food security are identified:

- macroeconomic risks - due to the decline in investment attractiveness of the domestic real economy and competitiveness of domestic products, as well as the dependence of the major sectors of the economy on the external economic environment;

- technological risks - caused by the lagging behind the leading countries in the level of technological development of the domestic production base, differences in the requirements for food safety and the organization of a system for monitoring their compliance;

- agro-environmental risks - due to adverse climatic changes, as well as the consequences of natural and man-made emergencies;

- foreign trade risks - caused by fluctuations in market conditions and the application of state support measures in foreign countries. 
The existence of these risks creates threats to food security, which can lead to noncompliance with food safety criteria.

For a more detailed study of the macroeconomic risks impact on countries' food security, an econometric model was constructed. An econometric model is a function that describes the correlation-regression relationship between economic indicators, depending on the causal relationships between them; one or more of these indicators are treated as dependent variables and the other as independent. An important step in building any econometric model is to establish relationships between financial indicators that are not isolated, independent, but have direct and even inverse relationships. Considering the analysis of macroeconomic factors that determine food security, it was checked the connection between Food production index and Foreign direct investment, net inflows (\% of GDP), GDP growth (annual \%), GNI per capita growth (annual $\%$ ), Short-term debt ( $\%$ of total external debt), Tax revenue ( $\%$ of GDP), Total natural resources rents ( $\%$ of GDP), Trade ( $\%$ of GDP).

It was supposed that: $\mathrm{Y}$ is a dependent variable (Food production index); $\mathrm{X} 1$ is Short-term debt (\% of total external debt), X2 is GDP growth (annual \%), X3 is Foreign direct investment, net inflows (\% of GDP), X4 is GNI per capita growth (annual $\%$ ), X5 is Tax revenue ( $\%$ of GDP), X6 is Total natural resources rents ( $\%$ of GDP), $\mathrm{X} 7$ is Trade ( $\%$ of GDP).

It was constructed a regression multivariate econometric model to determine the impact of macroeconomic indicators on the Food production index, it was checked the adequacy of the model by Fisher's criterion. Let's check the factors for multicollinearity using Microsoft Excel. One way of checking this is to calculate a pair of correlation matrix. Matrix of paired correlations is shown in Table 9.

Table 9

Matrix of paired correlations

\begin{tabular}{||c|c|c|c|c|c|c|c|c|}
\hline & \multicolumn{1}{|c|}{ X1 } & X2 & X3 & X4 & X5 & X6 & X7 & y \\
\hline X1 & 1 & & & & & & & \\
\hline X2 & 0.955616 & 1 & & & & & & \\
\hline X3 & -0.90554 & -0.82329 & 1 & & & & & \\
\hline X4 & -0.92871 & -0.91974 & 0.899433 & 1 & & & & \\
\hline X5 & -0.7736 & -0.8766 & 0.674795 & 0.902882 & 1 & & & \\
\hline X6 & -0.95047 & -0.98094 & 0.808411 & 0.94696 & 0.891018 & 1 & & \\
\hline X7 & -0.95047 & -0.98094 & 0.808411 & 0.94696 & 0.891018 & 0.94696 & 1 & \\
\hline y & 0.790422 & 0.896572 & -0.57674 & -0.80774 & -0.87249 & -0.92106 & -0.87249 & 1 \\
\hline
\end{tabular}

In this case the variables $\mathrm{X} 1$ and $\mathrm{X} 2, \mathrm{X} 3, \mathrm{X} 4, \mathrm{X} 6, \mathrm{X} 7$ have a close relationship; $\mathrm{X} 2$ and $\mathrm{X} 4, \mathrm{X} 6, \mathrm{X} 7$; X4 and X5, X6, X7. The table shows that there is no link between Short-term debt ( $\%$ of total external debt) and other factors; foreign direct investment, net inflows ( $\%$ of GDP) has the most to do with other factors.

Therefore, the construction of a regression multivariate model must be performed on the basis of the stepwise exclusion of independent variables. The results of the most appropriate model that has the highest performance and compliance are summarized in Table 3. 
So, the model looks like: $\mathrm{Y}=-329.789+0.225 \mathrm{X} 2+0.165 \mathrm{X} 3-1.808 \mathrm{X} 4+0.435$ X6.

Results of regression analysis

\begin{tabular}{||c|c|c|c|c||}
\hline \hline Indicator & Coefficients & Standard error & t-statistics & P-value \\
\hline Y-intersection point & -329.789 & 87.44775 & -3.77127 & 0.005456 \\
\hline $\mathrm{X} 2$ & 0.224991 & 0.059702 & 3.76857 & 0.005477 \\
\hline $\mathrm{X} 3$ & -0.16553 & 0.050498 & 3.277933 & 0.011222 \\
\hline $\mathrm{X} 4$ & -1.80769 & 1.022868 & -1.76727 & 0.115164 \\
\hline $\mathrm{X} 6$ & 0.435123 & 0.030678 & 3.01278 & 0.021765 \\
\hline
\end{tabular}

Thus, it can be drawn the following conclusions:

- the coefficient at X2 shows that with an increase in X2 (GDP growth (annual\%)) by $1 \%$, the Food production index will increase by 0.225 ;

- the coefficient at X3 shows that by increasing X3 (Foreign direct investment, net inflows ( $\%$ of GDP)) by $1 \%$, Y (Food production index) will decrease by 0.165 ;

- parameter X4 is not significant in this case, as evidenced by a P-value equal to 0.115164 ;

- the coefficient at X6 shows that with an increase in X6 (Total natural resources rents (\% of GDP)) by $1 \%$, Y (Food production index) will increase by 0.435 .

Hence, it can be concluded that GDP growth (annual \%) and other Total natural resources rents ( $\%$ of GDP) have the greatest impact on the Food production index. In Table 11, there were presented the results of the regression statistics conducted using Microsoft Excel.

Table 11

Regression statistics (4 factors)

\begin{tabular}{||l|c||}
\hline \multicolumn{1}{|c|}{ Indicator } & Value \\
\hline Multiple R & 0.957638 \\
\hline R-square & 0.917071 \\
\hline Normalized R-square & 0.885973 \\
\hline Standard error & 20.5556 \\
\hline Observation & 108 \\
\hline
\end{tabular}

There were analyzed the results of the model:

- $\mathrm{R}=0.957638$ is multiple correlation coefficient - characterizes the relationship between the dependent and independent variables; in this case, the relationship between the Food production index and the factors identified above is very large;

- the model's coefficient of determination is the proportion of the explained variance of the deviation of the dependent variable from its mean, therefore, $91 \%$ of the change in the Food production index is explained by a change in certain factors, and the influence of other factors is $9 \%$.

Table 5 presents the results of the least-squares variance analysis. Therefore, according to the results of the table, it can be concluded that the model is adequate, 
because the Fisher adequacy criterion $F(4,7)=29.49$ is more than the Fisher criterion value table (0.000112).

Analysis of variance (3 factors)

\begin{tabular}{|l|c|c|c|c|c||}
\hline \hline \multicolumn{1}{|c|}{ Indicator } & df & $\begin{array}{c}\text { Sum Square } \\
\text { (SS) }\end{array}$ & $\begin{array}{c}\text { Mean Square } \\
\text { (MS) }\end{array}$ & F-criterion & $\begin{array}{c}\text { F-criterion } \\
\text { significance }\end{array}$ \\
\hline Regression & 3 & 37380.65 & 12460.22 & 29.48934 & 0.000112 \\
\hline Remainder & 8 & 3380.263 & 422.5329 & $\mathrm{x}$ & $\mathrm{X}$ \\
\hline Total & 11 & 40760.92 & & $\mathrm{x}$ & $\mathrm{X}$ \\
\hline
\end{tabular}

Thus, it was made a comprehensive analysis of the multifactorial regression model of the dependence of Food production index on Foreign direct investment, net inflows ( $\%$ of GDP), GDP growth (annual \%), GNI per capita growth (annual $\%$ ), Short-term debt ( $\%$ of total) external debt), Tax revenue ( $\%$ of GDP), Total natural resources rents ( $\%$ of GDP), Trade ( $\%$ of GDP). The analysis has shown that for the analysis of Food production index it is effective to build a regression model, because it allows not only to estimate the degree of influence of factor traits on the result, but also to most effectively predict the size of the Food production index for the future.

Next, we describe the economic content of the obtained connection characteristics for the Food production index. An increase of 1\% in GNI per capita growth will reduce the value of the Food production index by $1.808 \%$; while a $1 \%$ increase in GDP growth; Foreign direct investment, net inflows; Total natural resources rents will increase the Food production index by $0.225 \% ; 0.165 \% ; 0.435 \%$ respectively. The economic meaning of the relationship equation (1) is evidence that the Food production index affects GNI per capita growth, GDP growth, Foreign direct investment, net inflows, Total natural resources rents.

\section{DISCUSSION}

Despite significant problems in the area of food security and provision, the knowledge system of the general population, children and young people about these problems is almost completely destroyed or lacking. A deliberate state policy on ensuring food security of Ukraine is necessary. One of the steps to become familiar with state food security policy is to consider the criteria. This state system of consumption standards should regulate the basic normative levels of the population consumption. Food security criteria are considered to be the threshold value of an indicator, which is the limit beyond which the food situation in a country (region) is considered dangerous.

So, Natalia Vasylieva, Harvey James and Jr. (2020) write that many countries are in talks to create a fairer and more competitive and predictable trading system. Our analysis of exports and imports of the studied countries confirms this statement. Alina Bukhtiarova, Arsen Hayriyan, Victor Chentsov and Sergii Sokol (2019) write 
that the level of agricultural development determines the state of food security of the population and the social and economic situation in the country. We agree with Olga Vyshnevska, Olena Kaliuzhna, Inna Irtyshcheva (2019), they claim that the urgent need is to ensure food security of the world, which necessitates the regulation of infrastructure provision for the agricultural market of all continents and regions of the world. The competitiveness of agricultural products should be considered not only in terms of its value, but also in terms of quality, safety and environmental friendliness.

Anton Stolitnii, Vitalii Makhinchuk (2019) write that the development of the world economy is taking place against the backdrop of global challenges that affect the functioning of social reproduction mechanisms. The world is currently undergoing major global changes and transformations. Maksym Odnorog, Nataliia Kraus, Liudmyla Savchuk (2019) argue that the agricultural market in Ukraine will become the basis of food security and financial well-being of the population, which in general will mean stability in the country's social life. Our study confirms the above, based on the analysis of the dynamics and forecast of Imports, Exports and Total consumption Wheat and corn in Ukraine and the EU.

Svitlana Rogach, Larysa Vdovenko, Oleh Polishchuk (2019) argue that a decisive feature of European financial support for agriculture is to regard it as one of the factors in the development of the European Union's financial system. Hanna Fedosieieva (2019) notes that sustainable development of agricultural producers in the world market can be achieved by: continuous development of scientific research, creation of favorable conditions for foreign investment; improvement of material and technical base of agricultural producers; development of the internal market for environmentally friendly products; improvement of legal regulation of relations in the agricultural sector; implementation of effective social and economic policy of rural development. The statement about foreign investment is also confirmed in our study, namely - an increase of $1 \%$ foreign direct investment, net inflows will increase the Food production index by $0.165 \%$.

Our research and comprehensive analysis of the multifactorial regression model revealed the presence of Food production index dependence on Foreign direct investment, GDP growth, GNI per capita growth, Short-term debt, Tax revenue, Total natural resources rents and Trade.

Consideration of the food security system as an object of governance for Ukrainian society actualizes the need for government intervention through appropriate policies. Such an object is extremely specific, because the efficiency and balance of the food supply system depends on the quality of life of the population, the level of economic security of the country and its regions, its competitiveness in the world market. This system is particularly sensitive to the effects of external and internal environmental factors, so its management falls within the responsibility of the state as an institution that is obliged to care for its citizens. Therefore, managing a country's or region's food security system is a prerequisite for the effective functioning of this food market link. 
Even with a high level of market development (the example of many developed countries in the world) with transparent competitive relations, external control by the state and the public must remain.

In the presence of numerous distortions of the domestic agrarian sector, regional differentiation and quality competition from the European agricultural producer, the regulation of food supply should take on more directive features. In particular, there is a structural imbalance between production and domestic consumption, concentration of production in own farms, high level of dependence on imports, low export orientation due to significant competition in foreign food markets, the problem of reduction of agricultural land suitable for agricultural activity, a decrease in the purchasing power of the local population and a weak institutional environment. These problems pose risks to guaranteeing the country's food security as a component of national food security.

Thus, looking at a certain number of indicators, without even analyzing each of them in details, and analyzing individual ones, we can say that the level of food security of Ukraine is at an unsatisfactory level. The analysis of even some data shows that most of them are quite low, although there is some increase. In our view, the system of indicators is not able to meet the actual needs of the population, but these criteria indicate the problem areas and help in their tracking, but with their constant control. And the results of the analysis concretize and provide an in-depth analysis of the food security situation in the country over several years.

Therefore, the conclusions of the study of the obtained connection characteristics for the Food production index are interesting. An increase of $1 \%$ in GNI per capita growth will reduce the value of the Food production index by $1.808 \%$; while a $1 \%$ increase in GDP growth; Foreign direct investment, net inflows; Total natural resources rents will increase the Food production index by $0.225 \% ; 0.165 \% ; 0.435 \%$ respectively. The economic meaning of the relationship equation (1) is evidence that the Food production index affects GNI per capita growth, GDP growth, Foreign direct investment, net inflows, Total natural resources rents.

\section{REFERENCES}

Babenko V., Kulczyk Z., Perevozova I., Syniavska O., Davydova O. (2019a), Factors of Development of International e-Commerce in the Context of Globalization, "CEUR Workshop Proceedings", http://ceur-ws.org/Vol-2422/paper28.pdf (20.03.2020).

Bukhtiarova A., Hayriyan A., Chentsov V., Sokol S. (2019), Modeling the impact assessment of agricultural sector on economic development as a basis for the country's investment potential, "Investment Management and Financial Innovations", 16(3), DOI: 10.21511/ imfi.16(3).2019.21.

Cabinet of Ministers of Ukraine Decree No. 1379 of December 5, 2007 "Some Issues of Food Security", http://zakon2.rada.gov.ua/laws [in Ukrainian] (19.02.2020).

"Concept of improvement of food security of the CIS Member States", Approved by the Decision of the CIS Council of Heads of Government on the November 19, 2010, http://zakon2.rada.gov. ua/laws [in Ukrainian] (19.02.2020). 
Consumption of food products per capita worldwide, http://www.helgilibrary.com/pages/data (20.03.2020).

FAOStat. (2020), Statistics Data: the Food and Agriculture Organization of the United Nations, http://www.fao.org/faostat/ en/\#data (16.03.2020).

Fedosieieva H. (2019), Sustainable development of agricultural producers is a condition for their successful functioning in the world market, "Baltic Journal of Economic Studies", Vol. 5, No. 1, http://dx.doi.org/10.30525/2256-0742/2019-5-1-218-223 (01.03.2020).

Ferrara G. (2018), Innovation in Agro-Food: A Geographical Perspective, "Journal of Food Products Marketing”, 24(1), https://doi.org/10.1080/10454 446.2017.1266554 (13.03.2020).

Flies E. J., Brook B. W., Blomqvist L., Buettel J. C. (2018), Forecasting future global food demand: A systematic review and meta-analysis of model complexity, "Environment International", https://doi.org/10.1016/j.envint.2018.07.019 (20.02.2020).

Giscard Assoumou-Ella (2019), External Trade and Food Security: The Case of CEMAC Countries, "Journal of Food Security", Vol. 7, No. 2, http://pubs.sciepub.com/jfs/7/2/5, Published by Science and Education Publishing, DOI: 10.12691/jfs-7-2-5 (20.07.2020).

Global Food Security Index, http://foodsecurityindex.eiu.com (06.03.2020).

Guzhva I., Nebotov P., Ivanov Y. (2019), Foreign trade policy for integration into global value chains, "Baltic Journal of Economic Studies", Vol. 5, No. 2, http://dx.doi.org/10.30525/22560742/2019-5-2-24-29 (20.03.2020).

Khalatur S., Radzevicius G., Velychko L., Fesenko V., Kriuchko L. (2019), Global deoffshorization and its impact on the national and regional economies of eastern european countries, "Problems and Perspectives in Management", 17(3), DOI: 10.21511/ppm.17(3).2019.24 (18.03.2020).

Khalatur S., Stachowiak Z., Zhylenko K., Honcharenko O., Khalatur O. (2019), Financial instruments and innovations in business environment: European countries and Ukraine, "Investment Management and Financial Innovations", 16(3), http://dx.doi.org/10.21511/ imfi.16(3).2019.25 (18.03.2020).

Methodology for determining the main indicators of food security, Resolution of the Cabinet of Ministers of Ukraine No. 1379 of December 5, 2007, http://zakon2.rada.gov.ua/laws/show/13792007-\%D0\% BF [in Ukrainian] (19.02.2020).

Odnorog M., Kraus N., Savchuk L. (2019), System-forming innovative institutions of the agrarian market, "Baltic Journal of Economic Studies", Vol. 5, No. 3, http://dx.doi.org/10.30525/22560742/2019-5-3-152-158 (16.03.2020).

Official website of the State Statistics Committee, www.ukrstat.gov.ua (26.01.2020).

Olarinre Abiola Adebunmi, Oladeebo Job Olatunji, Olarinde Luke O. (2019), Effects of Land Management Practices on Food Insecurity among Farming Households in Osun State, Nigeria, "Journal of Food Security", Vol. 7, No. 3, http://pubs.sciepub.com/jfs/7/3/5, Published by Science and Education Publishing, DOI: 10.12691/jfs-7-3-5 (16.03.2020).

On approval of Methodological recommendations for calculating the level of economic security of Ukraine, Order of October 29, 2013, № 1277, Ministry of Economic Development and Trade of Ukraine, http://document.ua/pro-zatverdzhennja-metodichnih-rekomendacii-shodo-rozahunku-doc168080.html [in Ukrainian] (20.03.2020).

On Food Security of Ukraine, Law of Ukraine, on December 22, 2011 No. 4227-IV, http://search. ligazakon.ua/1_doc2.nsf/link1/JF6GI01A.html [in Ukrainian] (20.03.2020).

On National Security of Ukraine, Law of Ukraine, on June 21, 2018 No. 2469-VIII, https://zakon. rada.gov.ua/laws/show/2469-19 [in Ukrainian] (10.03.2020). 
Onyango George Nyakoyo, Abuya Isaac Odhiambo (2020), Stakeholder Involvement and Implementation of Sustainable Community Food Security Projects in Nyando Basin, Kenya, "Journal of Food Security", Vol. 8, No. 1, http://pubs.sciepub.com/jfs/8/1/3, Published by Science and Education Publishing, DOI: 10.12691/jfs-8-1-3 (12.06.2020).

Order of the Ministry of Economy of Ukraine "On Approval of the Methodology of Calculating the Level of Economic Security of Ukraine" on 02.03.2007, No. 60, http://search.ligazakon. ua/1_doc2.nsf/link1/ME07222.html [in Ukrainian] (20.03.2020).

Petrova I., Albdrane M. (2019), Peculiarities of staff motivation at small food industry enterprises, "Social and labour relations: theory and practice", 9(1), DOI: 10.21511/slrtp.9(1).2019.03 (30.01.2020).

Pinstrup-Andersen P. (2009), Food security: definition and measurement, "Food Sec.", No. 1.

Rogach S., Vdovenko L., Polishchuk O. (2019), Agriculture of Ukraine under the joint policy of the European Union, "Baltic Journal of Economic Studies", Vol. 5, No. 3, http://dx.doi. org/10.30525/2256-0742/2019-5-3-178-183 (05.03.2020).

Sardak S., Samoylenko A. (2014), National Economies Intellectualization Evaluating in the World Economy, "Economic Annals-XXI", 9-10(2).

Sardak S., Radziyevska S., Prysiazhniuk Y. (2019), Civilizational structure of regional integration organizations, "Przegląd Strategiczny", 12, DOI: 10.14746/ps.2019.1.4.

Schwab K. (ed.) (2019), The Global Competitiveness Report 2019 (648 p.), World Economic Forum, Geneva, http://www3.weforum.org/docs/WEF_TheGlobalCompetitivenessReport2019.pdf (26.03.2020).

Stolitnii A., Makhinchuk V. (2019), Priorities for the development of the economy of the USA and some European countries, "Baltic Journal of Economic Studies", Vol. 5, No. 5, https://doi. org/10.30525/2256-0742/2019-5-5-151-154 (11.03.2020).

Tarek Ben Hassen, Hamid El Bilali (2019), Food Security in the Gulf Cooperation Council Countries: Challenges and Prospects, "Journal of Food Security", Vol. 7, No. 5, http://pubs.sciepub.com/jfs/7/5/2, Published by Science and Education Publishing, DOI: 10.12691/jfs-7-5-2 (11.03.2020).

The World Bank (2020a), Foreign direct investment, net inflows (\% of GDP), https://data.worldbank. org/indicator/bx.klt. dinv.wd.gd.zs (20.01.2020).

The World Bank (2020b), World Development Indicators, http://databank.worldbank.org/data/reports.aspx?source=world-development-indicators (11.01.2020).

Tumuhe C. L., Kusiima J., Sekamate W., Mulumba M. (2020), Food Stuff Available on Market Stalls and Restaurants in Rural Urban Centers; a Case of Kagadi Town, Uganda, "Journal of Food Security", Vol. 8, No. 1, http://pubs.sciepub.com/jfs/8/1/4, Published by Science and Education Publishing, DOI: 10.12691/jfs-8-1-4 (17.06.2020).

Vasylieva N. (2019), Problems and Prospects of Food Security in Ukraine, "Bulgarian Journal of Agricultural Science", 25(4), http://www. agrojournal.org/25/04-08.pdf (21.03.2020).

Velychko O., Velychko L. (2017), Management of inter-farm use of agricultural machinery based of the logistical system "BOA», "Bulgarian Journal of Agricultural Science", 23(4), https:// www.scopus.com/record/display.uri?eid=2-s2.0-85026907558\&origin=inward\&txGid=c8c 5eeec2907ddff28f820cc69cade12 (20.03.2020).

Vyshnevska O., Kaliuzhna O., Irtyshcheva I. (2019), Infrastructure provision of the agrarian market in the globalized environment, "Baltic Journal of Economic Studies", Vol. 5, No. 5, https:// doi.org/10.30525/2256-0742/2019-5-5-39-46 (22.03.2020).

Yosef Alamri, Abdulaziz Al-Duwais (2019), Food Security in Saudi Arabia (Case Study: Wheat, Barley, and Poultry), "Journal of Food Security", Vol. 7, No. 2, http://pubs.sciepub.com/ jfs/7/2/2, Published by Science and Education Publishing DOI: 10.12691/jfs-7-2-2. 


\begin{abstract}
The purpose of the study is to review the academic literature on food security issues in order to examine the indicators of rational and minimal nutrition, facilitating the analysis of the existing system of indicators by which to assess the state of the food security system in a country. The aim of the article is to investigate and demonstrate the imperatives behind the formation of Ukraine's national (food) security in the context of globalization. National food security in the broad sense should be considered as the state of the economy, and more narrowly - as the guaranteed ability of a state to meet the needs of the population by providing each citizen with the required volume, range and quality of food at a level that ensures the health and intellectual development of the individual, based on the principles of self-sufficiency of basic products and their economic and physical accessibility, regardless of the influence of external and internal factors. The Global Food Security Index Ranks of the European Union and Ukraine are analyzed. Consumer expenditure on food consumed at home in Ukraine is analyzed in the article. Average food security indicators of the EU and Ukraine are analyzed for 2001-2018, in particular for food exports, food imports, food production index, food, beverages and tobacco. The dynamics and forecasts of wheat and maize harvest and crop production in Ukraine and the EU are compared. The analysis of the Suite of Food Security Indicators of the EU and Ukraine is presented alongside a comprehensive analysis of the multifactor regression model of Food Production Index from foreign direct investment, net inflows, GDP growth, GNI per capita growth, short-term debt, tax revenue, total natural resources rents, and trade. The analysis has shown that for the analysis of the food production index it is effective to build a regression model, because it allows not only to estimate the degree of influence of the factor on the result, but also to most effectively predict the size of the food production index for the future.
\end{abstract}

Keywords: agriculture, investment, food, indicators, national security, imports, exports

\title{
MIĘDZYNARODOWE CZYNNIKI KSZTALTUJĄCE WSPÓLCZYNNIK BEZPIECZEŃSTWA NARODOWEGO (ŻYWNOŚCIOWEGO) UKRAINY W WARUNKACH GLOBALIZACJI
}

\section{STRESZCZENIE}

Celem pracy jest przegląd literatury naukowej z zakresu bezpieczeństwa żywnościowego i rozważenie wskaźników racjonalnego i minimalnego żywienia, co pozwoli na analizę istniejącego systemu wskaźników służących do oceny stanu systemu bezpieczeństwa żywnościowego w kraju. Celem artykułu jest zbadanie i uzasadnienie wpływu czynników kształtujących bezpieczeństwo narodowe (żywnościowe) Ukrainy w kontekście globalizacji. Szeroko rozumiane bezpieczeństwo żywnościowe państwa należy traktować jako stan gospodarki, a ściślej - jako gwarantowaną zdolność państwa do zaspokojenia potrzeb ludności poprzez zapewnienie każdemu obywatelowi żywności w wymaganej ilości, różnorodności i jakości, na poziomie zapewniającym zdrowie i rozwój intelektualny jednostki, w oparciu o zasady samowystarczalności podstawowych produktów oraz ich ekonomicznej i fizycznej dostępności, niezależnie od wpływu czynników zewnętrznych i wewnętrznych. Przeanalizowano pozycję Unii Europejskiej i Ukrainy w Światowym Indeksie Bezpieczeństwa Żywności (Global Food Security Index). W artykule zbadano ponoszone na Ukrainie wydatki konsumpcyjne na żywność spożywaną w domu. Przeanalizowano średnie wskaźniki bezpieczeństwa żywnościowego UE i Ukrainy w latach 2001-2018, w szczególności: eksport żywności; import żywności; indeks 
produkcji żywności; żywność, napoje i tytoń. Porównano dynamikę i prognozy zbiorów pszenicy i kukurydzy oraz produkcji roślinnej na Ukrainie i w UE. Przedstawiono analizę zestawu wskaźników bezpieczeństwa (Suite of Food Security Indicators) UE i Ukrainy. Kompleksowo przeanalizowano wieloczynnikowy model regresji wskaźnika produkcji żywności na podstawie bezpośrednich inwestycji zagranicznych, napływów netto, wzrostu PKB, wzrostu DNB na mieszkańca, zadłużenia krótkoterminowego, dochodów podatkowych, renty z zasobów naturalnych ogółem i handlu. Przegląd wykazał, że w celu analizy wskaźnika produkcji żywności przydatne jest zbudowanie modelu regresji, ponieważ pozwala on nie tylko oszacować stopień wpływu różnych czynników, ale także najskuteczniej przewidzieć wielkość indeksu produkcji w przyszłości.

Słowa kluczowe: rolnictwo, inwestycje, żywność, wskaźniki, bezpieczeństwo narodowe, import, eksport 
